\title{
Sinking rate versus cell volume relationships illuminate sinking rate control mechanisms in marine diatoms
}

\author{
Anya Waite ${ }^{1, *}$, Anne Fisher ${ }^{2}$, Peter A. Thompson ${ }^{3}$, Paul J. Harrison ${ }^{4}$ \\ ${ }^{1}$ School of Biological Sciences, Victoria University of Wellington, PO Box 600, Wellington 6015, New Zealand \\ ${ }^{2}$ Department of Botany, University of British Columbia, Vancouver, British Columbia, Canada V6T 1 Z4 \\ ${ }^{3}$ Department of Aquaculture, University of Tasmania, PO Box 1214, Launceston, Tasmania 7250, Australia \\ ${ }^{4}$ Departments of Botany and Oceanography, University of British Columbia, Vancouver, British Columbia, Canada V6T 1 Z4
}

\begin{abstract}
It has been shown that for dead marine diatom cells or diatom cells which are severely stressed metabolically, larger cells sink faster than small cells as dictated by Stokes' Law. In these cases, the slope of the sinking rate versus cell volume relationship within a culture reaches a maximum. Within cultures of rapidly dividing cells, larger cells' sinking rate is reduced physiologically to that of smaller cells and the slope of this relationship approaches zero. In several marine diatom species between 5 and $100 \mu \mathrm{m}$ in diameter, deviations from the maximum slope of the volume versus sinking rate relationship could be used to quantify the physiological reduction of sinking rates. This allowed us to differentiate 2 different components of sinking rate control, the ballasting component (driven by changes in cell composition and volume) which, when dominant, causes sinking rates to be proportional to cell volume and the energy-requiring, protoplast and vacuolar component which, when active, allows sinking rates to become independent of cell volume. Across the 9 species of diatoms examined. including the 3 single-celled species (Ditylum brightwellii. Thalassiosira pseudonana, and $T$. weissflogii), 4 chain-forming coastal bloom diatoms (T. aestivalis, Skeletonema costatum, Chaetoceros debilis and C. compressum) and 2 large floating open ocean species (Ethmodiscus sp. and entire Rhizosolenia spp. mats), there was a strong correlation between log cell volume and sinking rate only for cells that were metabolically inactivated either through extended dark treatment or through treatment with the respiratory inhibitor $\mathrm{KCN}$. This was true both within and between cultures. However, no correlation between sinking rate and cell volume was found for rapidly growing cells maintained at saturating irradiances. This supports the notion that there is no obligate correlation between cell volume and sinking rate for metabolically active cells. This potential for cellular modification of the sinking rate versus volume relationship suggests that physiological state may be an important feature to include in models where carbon flux is predicted on the basis of particle size spectra. We suggest that the minimum cell volume necessary for active sinking rate control is ca $200 \mathrm{~mm}^{3}$, and that this represents a lower limit for Villareal's (1988; Deep Sea Res 35:1037-1045) theoretical minimum volume necessary for positive buoyancy.
\end{abstract}

KEY WORDS: Bacillariophyceae - Sinking rate Carbon content Stokes' Law. Thalassiosira pseudonana. $T$ weissflogii. Skeletonema costatum

\section{INTRODUCTION}

Coastal spring diatom blooms are often the periods of highest yearly new production and carbon sedimentation in the ocean (Goering et al. 1973). The sinking dynamics of bloom diatoms are an integral part of their

\footnotetext{
- Present address: Centre for Water Research, Dept of Environmental Engineering, University of Western Australia, Nedlands, WA.6907, Australia.E-mail: waite@cwr.uwa.edu.au
}

life history (Smetacek 1985), and are directly influenced by the physiological status of diatom cells as determined by factors such as growth irradiance (Eppley et al. 1967, Anderson \& Sweeny 1977, Bienfang et al. 1983, Waite et al. 1992a, b). Sinking rate changes also affect both the probability and rate of aggregate formation, which in turn causes accelerated sedimentation events (Jackson \& Lochmann 1993).

The importance of ballast in modifying algal sinking rates has been well documented in freshwater and 
marine cyanobacteria, with carbohydrate the primary substance used (Kromkamp \& Mur 1984, Kromkamp et al. 1988, Villareal \& Carpenter 1990, Ibelings et al. 1991). In general, the buoyancy responses of cells whose sinking rates depend entirely on ballasting changes often occur on the order of hours, with a diel periodicity associated with the accumulation of carbohydrate as photosynthate in the daytime and the reduction in carbohydrate content at night through respiration. Diatoms, however, are thought to regulate their buoyancy energetically (Waite et al. 1992b, E. Peters unpubl.), and the role of biochemical ballasting in modifying diatom sinking rates is variable: covariation of sinking rates with the accumulation of intracellular carbohydrate may be important in larger Rhizosolenia sp. (Villareal \& Carpenter 1990) but might be unimportant for the species Thalassiosira weissflogii and Ditylum brightwellii (Fisher \& Harrison 1996, Fisher et al. 1996). If ballasting is important in determining sinking rates, sinking rates should be amplified by increases in cell volume (Villareal 1988).

Gross \& Zeuthen (1948) originally suggested that low sinking rates in diatoms might be controlled through the maintenance of low turgor pressure through a steady expenditure of energy. Our recent study (Waite et al. 1992b) indicates that cells of Ditylum brightwellii generally maintain low sinking rates through energy expenditure during exponential growth, and lose the ability to maintain low sinking rates when deprived of energy through metabolic inhibition or after lengthy periods in the dark. Work of Peters (unpubl.) further suggests that there is a light-dependent ionic component which affects sinking rates in the short term through changes in vacuolar ion densities, and that the respiratory energy expenditure which decreases sinking rates actually does so by maintaining the turgor of the whole protoplast, not the vacuole. ATP-requiring ionic pumps are considered to be the method by which energetic turgor control is effected (Waite et al. 1992b)

In general, when sinking rates become high under severe energy depletion, cell sinking rates are proportional to the square of the cell radius, as dictated by Stokes' Law (Waite et al. 1992b). At this point, the biochemical composition of the cells in combination with their volume and shape must influence the maximum sinking rate. Thus, under different physiological conditions, the importance of ballast, volume, and physiological reduction of cell density in determining sinking rates can change dramatically.

We suggest in this study that the influence of diatom cell physiology on sinking rates can be split into the 2 components: (1) cell biochemical composition (ballast) and volume (passive), and (2) energetic ionic vacuole and protoplast regulation (active). In this study we measure the second, active component of diatom sink- ing rate control by demonstrating the absence of a clear relationship between cell volume and cell sinking rate within a culture when cells are energy-saturated. In other words, since large cells in a culture consistently had higher sinking rates than small cells under physiological stress, but have similar sinking rates when healthy, the slope of the sinking rate versus volume relationship within a culture becomes indicative of the level of physiological sinking rate control engaged in by the cells, and a more sensitive indicator of physiological stress than increases in the mean culture sinking rate alone.

We documented changes in the sinking rate versus volume relationship of the 2 single-celled species Thalassiosira weissflogii and T. pseudonana, with their physiological state. We made assessments of active sinking rate control across a range of temperate and sub-arctic spring bloom species ( $T$. aestivalis, Skeletonema costatum, Chaetoceros compressum and $C$. debilis) and several large (cells $>100 \mu \mathrm{m}$ diam.) open ocean diatom species (mats of Rhizosolenia spp. and single cells of the huge floating diatom Ethmodiscus sp.). We suggest that the inability of unhealthy cells to modify the slope of the sinking rate versus volume relationship can be seen as evidence that primarily passive mechanisms control sinking rate changes, while the ability to do so constitutes an active control based on turgor regulation of the protoplast and vacuole. The sinking rate versus volume relationship thus allows us to differentiate quite simply between the different mechanisms of sinking rate control.

\section{MATERIALS AND METHODS}

Laboratory studies. Culture conditions: Cultures of the marine diatoms Thalassiosira pseudonana, $T$. weissflogii, $T$. aestivalis, Chaetoceros compressum, $C$. debilis and Skeletonema costatum were obtained from the Northeast Pacific Culture Collection (NEPCC Nos. $58,418,704,707,644$, and 18c, respectively), Dept of Oceanography, University of British Columbia, Vancouver, B.C., Canada. Triplicate $1 \mathrm{l}$ batch cultures of all species were grown in nutrient-saturated artificial seawater (ESAW; Harrison et al. 1980) with modifications as described in Waite et al. (1992b). Light levels were as detailed below. All experiments were conducted between early- and mid-log phase, Cultures were maintained at given light levels for several dilutions (10 to 30 doublings) before experiments were conducted. All cultures were maintained at $17^{\circ} \mathrm{C}$, bubbled gently with air and stirred constantly with a teflon-coated magnetic stir bar at $120 \mathrm{rpm}$.

For the solitary species (Thalassiosira weissflogii, $T$. pseudonana), cells were grown under a variety of 
continuous irradiances. The highest irradiance was saturating for a particular species, and cells were growing at their maximal growth rate $\left(\mu_{\max }\right)$. Reductions in this irradiance were achieved with layers of neutral density screening and increased distance from the light source. Cells were grown at a range of growth rates between 25 and $100 \%$ of $\mu_{\max }$. For $T$ pseudonana these irradiances were 10, 50, 90, and $160 \mu \mathrm{mol}$ photons $\mathrm{m}^{-2} \mathrm{~s}^{-1}$, at which growth rates were $0.38,1.00,1.30$, and $1.35 \mathrm{~d}^{-1}$ respectively $\left(\mu_{\max }=1.35\right.$ $\pm 0.06 \mathrm{~d}^{-1}$ ). For $T$. weissflogii, irradiances were 5, 10 , 40 , and $100 \mu \mathrm{mol}$ photons $\mathrm{m}^{-2} \mathrm{~s}^{-1}$, at which growth rates were $0.28,0.58,0.61$ and $0.70 \mathrm{~d}^{-1}$ respectively $\left(\mu_{\max }=0.70 \pm 0.05 \mathrm{~d}^{-1}\right)$.

For the 4 spring bloom diatoms (Thalassiosira aestivalis, Skeletonema costatum, Chaetoceros compressum and $C$. debilis) cultures were grown only at saturating light (ca $110 \mu \mathrm{mol}$ photons $\mathrm{m}^{-2} \mathrm{~s}^{-1}$ ).

Sinking rates: The sinking rates of all cultures were measured using the SETCOL method (Bienfang 1981) as modified by Waite et al. (1992b). Sinking rate measurements for all cultures were made over $3 \mathrm{~h}$, in the light (LT), in the dark (DK) and in the dark with KCN $\left(12 \mathrm{mmol} \mathrm{l}^{-1}\right.$ ) added to the settling column as a respiratory inhibitor. Sinking rate measurements for the 2 solitary species were made with cell number as a biomass index, using a Coulter Counter $\left.{ }^{(}\right)$with a TA-II accessory designed to split the counts into volume-specific channels. Counts of both species were made using the $70 \mu \mathrm{m}$ aperture. Sinking rates were calculated for the entire culture, and were then calculated separately for each of the 4 volume-channels of the Coulter Counter, which spanned $99 \%$ of cell abundance, to generate volume-specific sinking rates for the 2 species. Sinking rate measurements for the 4 chain-forming species were made with chlorophyll as a biomass index (extracted as below).

Biochemical measurements: Sub-samples from each culture were taken at time $t=0$ of the SETCOL measurement and filtered onto precombusted GF/F filters for measurement of in vitro chlorophyll, particulate organic carbon (POC), and particulate organic nitrogen (PON).

Chlorophyll a sub-samples were immersed in $10 \mathrm{ml}$ of $90 \%$ acetone, sonicated for $10 \mathrm{~min}$, and kept at $4^{\circ} \mathrm{C}$ for $24 \mathrm{~h}$ prior to measurement of in vitro fluorescence on a Turner Designs ${ }^{(1)}$ fluorometer (Parsons et al. 1984). POC and PON samples were stored frozen and desiccated until analysis on a Carlo Erba CHN analyser (Model NA 1500).

Dark perturbations: Cultures of the 2 solitary species Thalassiosira pseudonana and $T$. weissflogii were grown at 4 different irradiances (as above). For $T$. pseudonana, we grew $60 \times 1 \mathrm{l}$ cultures, 15 at saturating, and 15 grown at each of the 3 different limiting irradiances. For each growth irradiance, $3 \times 1 \mathrm{l}$ cultures were kept in the light, 3 were placed in the dark for 9 h, 3 for $25 \mathrm{~h}, 3$ for $48 \mathrm{~h}$, and 3 for $100 \mathrm{~h}$. After this treatment we measured the sinking rate of each individual culture over $3 \mathrm{~h}$ in the dark, sacrificing the entire culture for analysis. For the light cultures only, we measured sinking rates both in the light and in the dark, yielding the 0 and 3 h dark-treatment time points. Thus each measurement was truly independent, and we had triplicate measurements of each treatment. For $T$. weissflogii, the experiment was identical, except that the limiting irradiances were different as detailed above.

For Thalassiosira pseudonana, sinking responses to darkness were then compared between cultures grown at different irradiances, and between cultures placed in the dark for different periods of time using a 1 -way analysis of variance (ANOVA). If significant differences were found between treatments, the ANOVA was followed by a Tukey test to determine which differences contributed significantly to the variance. Each plotted value represents the mean of 3 independent measurements, with cultures placed in the dark for a given time period. No consecutive time series data were used, making each measurement truly independent. For all statistical comparisons, the significance level was $p=0.05$.

This design can work only as long as no substantial changes in the species take place over the time all the experiments are run, so that all cultures grown at a given irradiance are truly identical. We tested this by looking for long-term trends in sinking rates and cell volume for the solitary species. For Thalassiosira pseudonana there was no long-term trend. However, for $T$. weissflogii, there was a significant reduction in sinking rate over the year in which the sinking experiments were conducted, and as a result at least 1 time point was significantly affected. Therefore, to resolve changes in sinking rates over time in the dark for this species, we re-did the experiment for cultures grown at saturating light only, using a different design. We placed $3 \times 12 \mathrm{l}$ high light grown batch cultures in the dark for 200 h (exactly as in Waite et al. 1992b). Therefore there were 2 separate data sets for $T$. weissflogii, one with separate cultures for each irradiance and time of dark exposure, and one in which we followed the trends in sinking rate versus time in 3 large cultures. The first independent-point data set was used only to resolve differences in sinking rates across different growth irradiances for $T$. weissflogii using an ANOVA. The second experiment with consecutive measurements over time on 3 cultures of $T$. weissflogii was used to define the temporal trends in sinking rates of cells grown at saturating irradiance and placed in the dark for $200 \mathrm{~h}$.

The respiration rates were estimated as in Waite et al. (1992b) from the change in carbon content within 
the cultures over time, expressed as picograms of carbon, and normalized per unit total biovolume in the culture to take into account any loss of cells or cell carbon through death or lysis in the culture over time which might otherwise bias our respiration rate upwards. We present data for Ditylum brightwelli from Waite et al. (1992b) for comparison purposes.

Other species. Measurements of sinking rates of the chain-forming species Thalassiosira aestivalis, Skeletonema costatum, Chaetoceros debilis and C. compressum were made on laboratory cultures at saturating irradiance, and in the dark with KCN. All field measurements were made as part of $T$. A. Villareal's cruise on the RV 'New Horizon' between Honolulu. Hawaii, and San Diego, California, USA, in May 1994. Individual suspended mats containing several species of $R$ hizosolenia were collected daily by SCUBA divers from the upper $10 \mathrm{~m}$ and brought on board for analysis. Only floating mats were used for this study. A $20 \mu \mathrm{m}$ mesh plankton net was towed for 5 to 10 min between 0 and $100 \mathrm{~m}$, and individual Ethmodiscus sp. cells were selected under a dissecting microscope and pipetted into filtered seawater for experimental use. We sub- jected floating samples of both Ethmodiscus sp. and Rhizosolenia spp. to treatment with $\mathrm{KCN}$, as described above, and observed changes in buoyancy status over several hours to determine the maximum sinking rate achieved

\section{RESULTS}

\section{Solitary species}

Growth irradiance versus sinking rate

Thalassiosira pseudonana cells grown at saturating irradiances had the highest sinking rates $\left(0.075 \mathrm{~m} \mathrm{~d}^{-1}\right)$, while cells grown at lower irradiance had lower sinking rates (Fig. 1A i). Sinking rates were highly correlated with cell volume increases over this range of irradiances $(\mathrm{R}=0.991, \mathrm{p}<0.01$; Fig. 1A ii; see also Fig. 3A ii) and with growth rate (Fig. $1 \mathrm{~A}$ iii). Overall, there was a hyperbolic relationship between cell sinking rate and growth irradiance, and sinking rates were generally proportional to cell volume changes which were deter-
A.Thalassiosira pseudonana

B. $T$ weissflogit

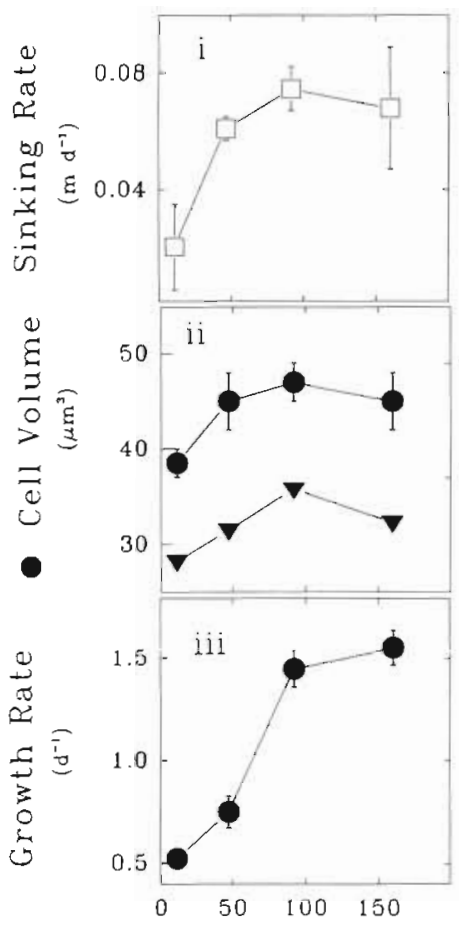

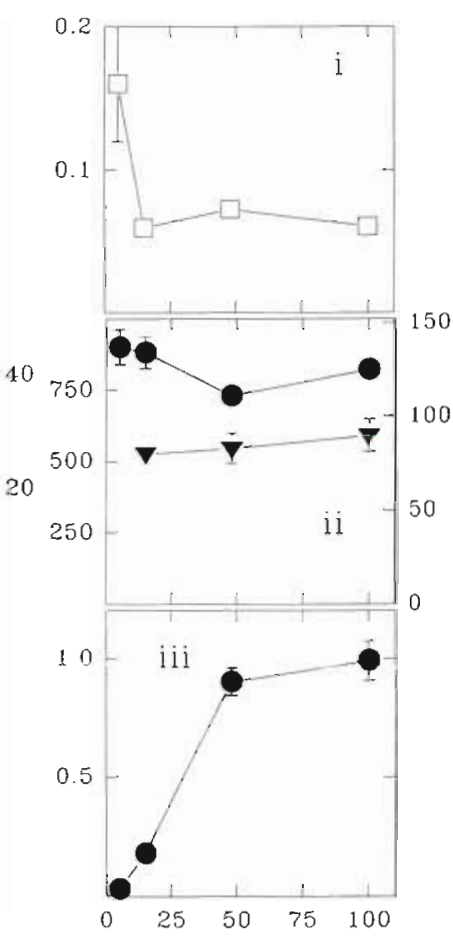

C. Ditylum brightwellii

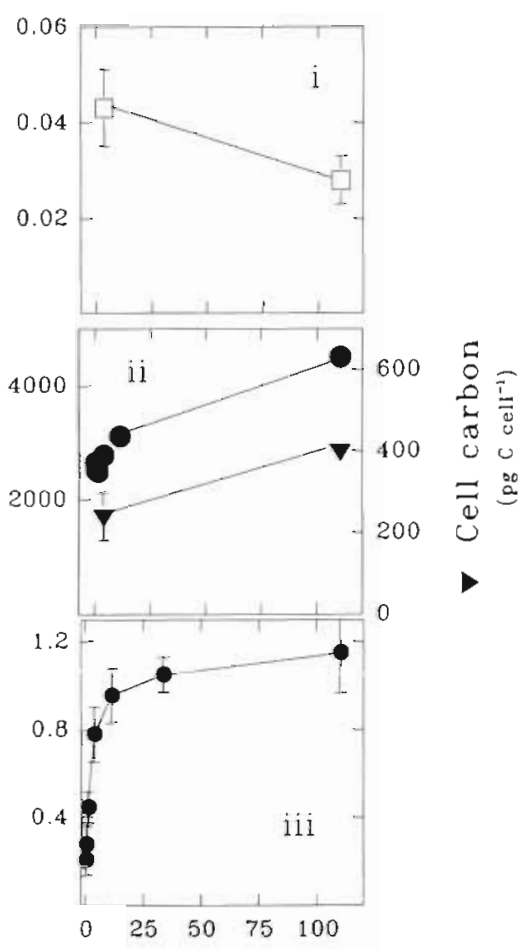

Growth Irradiance ( $\mu \mathrm{mol}$ photons $\mathrm{m}^{-2} \mathrm{~s}^{-1}$ )

Fig. 1. (A) Thalassiosira pseudonana, (B) $T$ weissflogii, (C) Ditylum brightwellii (trom Waite et al. 1992b). Effect of growth irradiance on the (i) sinking rate ( $\square$ ), (ii) cell carbon content ( $\mathbf{\text { ) }}$ ) and cell volume (O), and (iii) growth rate (O) of 3 solitary diatoms in semi-continuous batch cultures grown under continuous light at a variety of limiting and saturating irradiances. All measurements represent means from 3 or more cultures \pm 1 SD, and if error bars are not visible they are smaller than symbol size 
mined by the growth irradiance. Cell carbon content correlated directly with cell volume ( $p<0.05$; Fig. 1A ii).

Cells of Thalassiosira weissflogii grown at $5 \mu \mathrm{mol}$ photons $\mathrm{m}^{-2} \mathrm{~s}^{-1}$ had significantly higher sinking rates than cells grown at higher irradiances (Fig. 1Bi). The cultures grown at $5 \mathrm{mmol}$ photons $\mathrm{m}^{-2} \mathrm{~s}^{-1}$ had the highest sinking rates, but barely measurable growth rates. For $T$. weissflogii, there was no increase in cell volume with growth irradiance (Fig. 1B ii), though growth rate increased predictably with irradiance (Fig. 1Biii). There was no correlation between cell sinking rates and cell carbon across the range of irradiances measured (Fig. 1Bii; see also Fig. 3B). Under KCN, all $T$. weissflogii cultures showed a significant increase in sinking rates, from below $0.05 \mathrm{~m} \mathrm{~d}^{-1}$ to between 0.2 and $0.3 \mathrm{~m} \mathrm{~d}^{-1}$ (data not shown).

We show the data from Waite et al. (1992b), indicating that Ditylum brightwellii had a decrease in sinking rate with an increase in growth irradiance from 10 to $110 \mu \mathrm{mol}$ photons $\mathrm{m}^{-2} \mathrm{~s}^{-1}$, as well as an increase in cell volume and carbon (Fig. 1Ci-iii).

\section{Dark treatment time series experiments}

For Thalassiosira pseudonana grown at a saturating irradiance, and placed in the dark, carbon per cell decreased rapidly by over $50 \%$ over the first $10 \mathrm{~h}$ of the dark perturbation (Fig. 2A ii), after which it remained roughly constant at just under $50 \%$ of the initial C content. Cell volume decreased over time for T. pseudonana from about $35 \mathrm{\mu m}^{3}$ to only about $29 \mu^{3}{ }^{3}(17 \%$; Fig. 2A iii). Decreases in sinking rate (from 0.07 to $0.035 \mathrm{~m} \mathrm{~d}^{-1}$ ) were significantly correlated with decreases in cell carbon content (Fig. 2A i; see also Fig. 3Ai), which also underwent a reduction of $50 \%$. Though both $\mathrm{C}$ per cell and $\mathrm{C}$ per unit cell volume covaried with sinking rates, $C$ per unit cell volume described a higher portion of the variance in sinking rates $(98 \%$ ) than $\mathrm{C}$ per cell alone $(59 \%)$ (see Fig. 3A i, iii).

Thalassiosira pseudonana cells grown at $10 \mu \mathrm{mol}$ photons $\mathrm{m}^{-2} \mathrm{~s}^{-1}$ had significantly higher $10.06 \mathrm{com}-$ pared to $0.035 \mathrm{~m} \mathrm{~d}^{-1}$ ) sinking rates over all dark treat-
A. Thalassiosira pseudonana

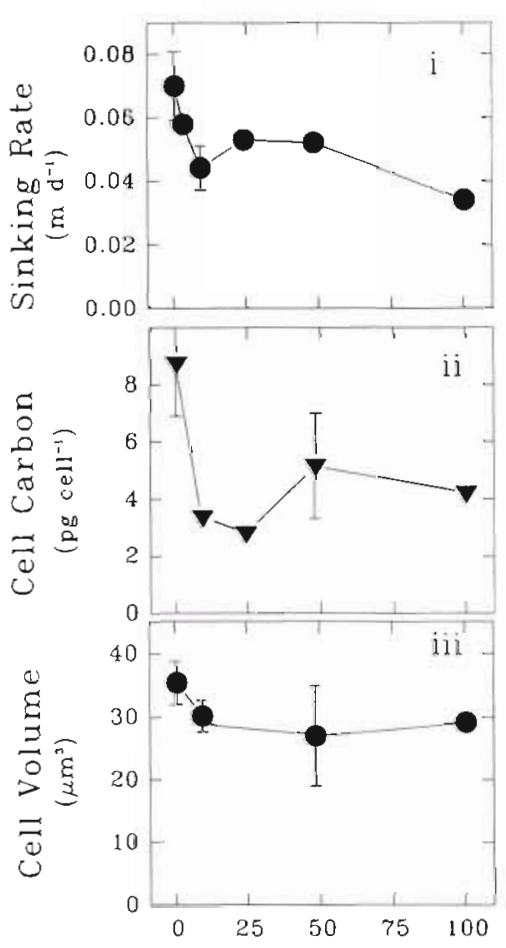

B. T werssflogii

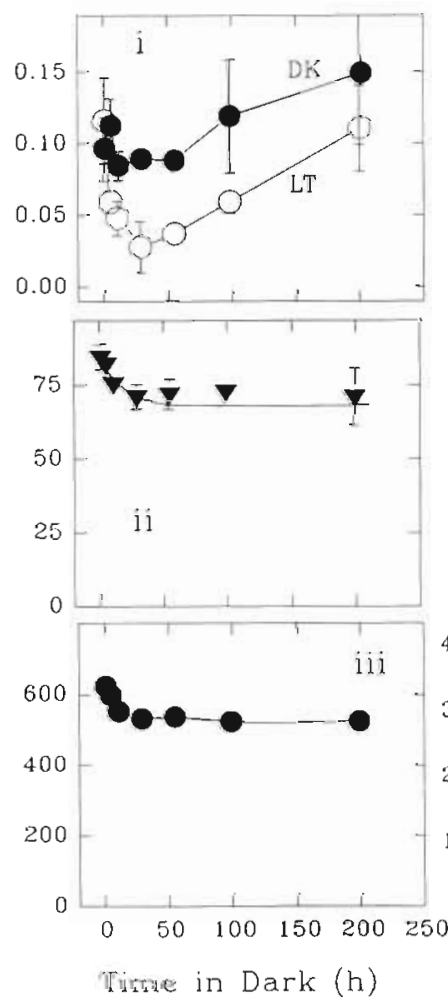

C. Ditylum brighlwellii

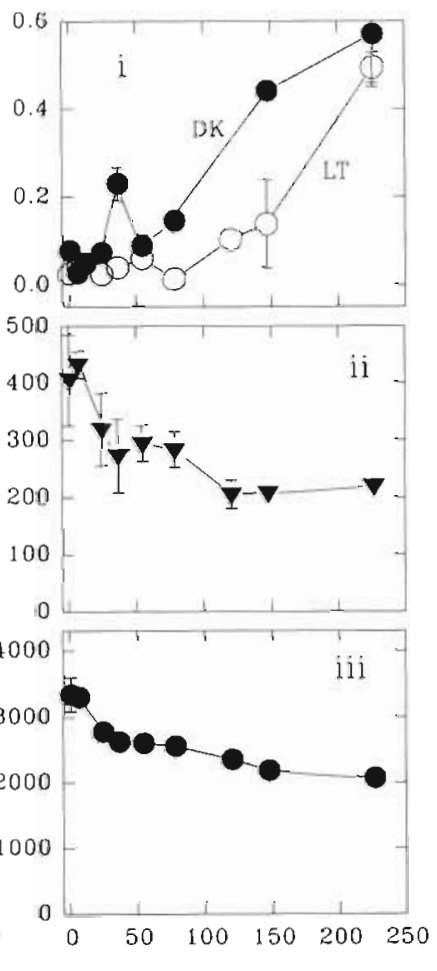

Fig. 2. (A) Thalassiosira pseudonana [sinking rates (SR) were not measured in the light], (B) $T$ weissflogii, (C) Ditylum brightwellii (from Waite et al. 1992b). Response of (i) sinking rate (O), (ii) cell carbon content ( $\mathbf{\nabla}$ ), and (iii) cell volume (-) of 3 diatom species (grown at saturating irradiances and continuous light) when cells are placed in the dark for periods up to $226 \mathrm{~h}$. For the upper-most panels, filled symbols represent the SR of cells placed in the dark (DK) and monitored over time; SR was measured over a $3 \mathrm{~h}$ period in the dark. Open symbols (O) represent the sinking rates of cells removed from the dark cultures at the indicated time and exposed to $3 \mathrm{~h}$ of saturating light (LT) during the SR measurement. All measurements represent means from 3 or more cultures $\pm 1 S D$, and if error bars are not visible they are smaller than symbol size 

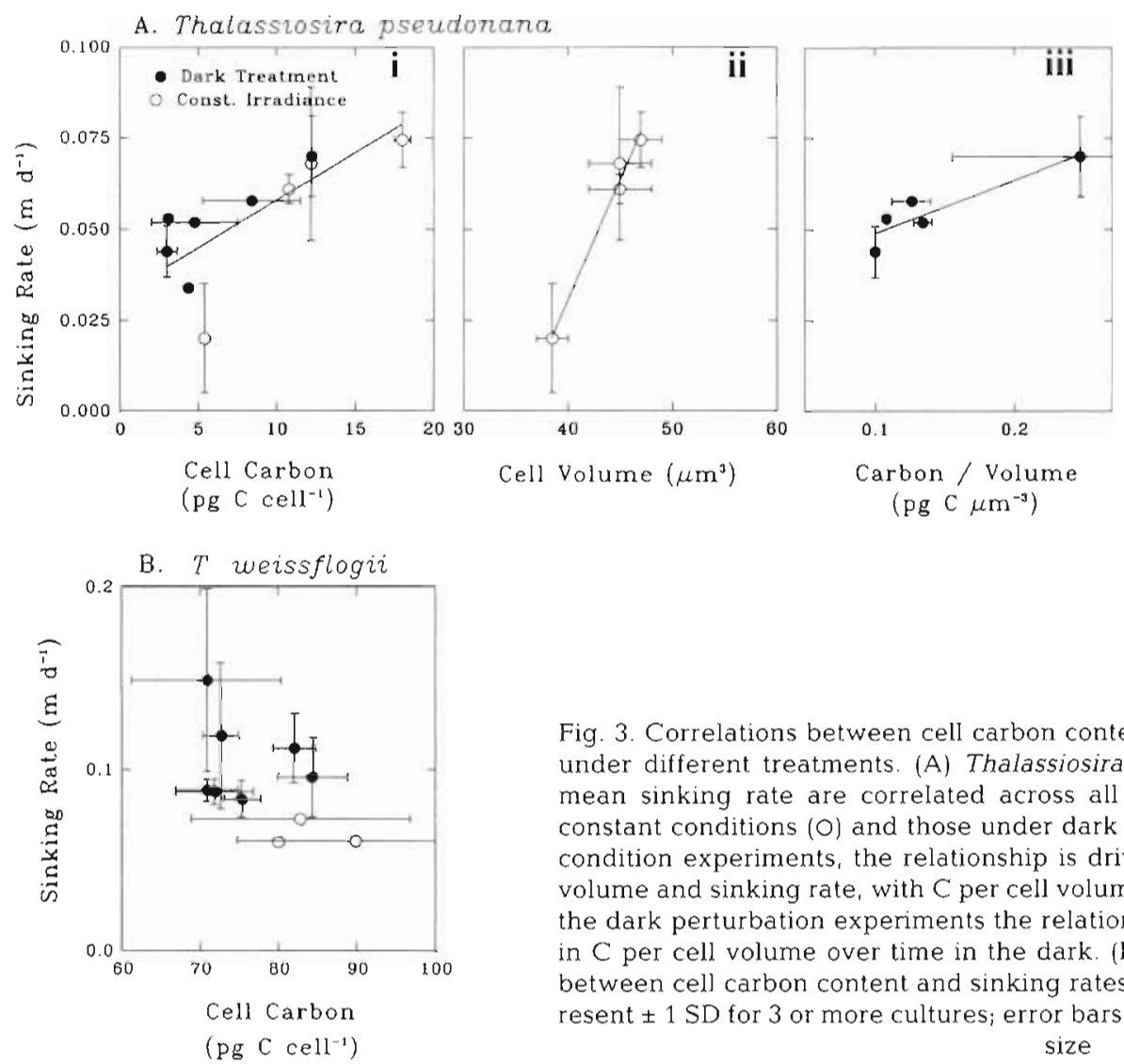

Fig. 3. Correlations between cell carbon content and sinking rates among cultures under different treatments. (A) Thalassiosira pseudonana. (i) Mean $\mathrm{C}$ cell ${ }^{-1}$ and mean sinking rate are correlated across all experiments including those under constant conditions ( $O$ ) and those under dark perturbations ( $)$; (ii) in the constant condition experiments, the relationship is driven by a strong correlation between volume and sinking rate, with $C$ per cell volume remaining roughly constant; (iii) in the dark perturbation experiments the relationship is driven by the rapid decrease in $\mathrm{C}$ per cell volume over time in the dark. (B) There is no significant correlation between cell carbon content and sinking rates for $T$ weissflogii. All error bars represent $\pm 1 \mathrm{SD}$ for 3 or more cultures; error bars are occasionally smaller than symbol size

ments than cells grown either at 100 or at $40 \mu \mathrm{mol}$ photons $\mathrm{m}^{-2} \mathrm{~s}^{-1}$ (ANOVA, $\mathrm{p}<0.05$, data not shown).

Cells of Thalassiosira weissflogii grown at a saturating irradiance and placed in the dark underwent a $16 \%$ decrease in volume over $200 \mathrm{~h}$ (Fig. 2B iii). Almost all of the volume reduction occurred within the first $30 \mathrm{~h}$ in the dark. Carbon content followed a similar pattern and decreased by a similar amount. The trends in the sinking rate time series changed at $t=30 \mathrm{~h}$. We therefore divided the time series into periods: (1) up to $30 \mathrm{~h}$, and (2) after $30 \mathrm{~h}$. The sinking rates of cells placed in the dark were correlated with cell volume for the first $30 \mathrm{~h}$, both decreasing by about $15 \%$. After $30 \mathrm{~h}$, sinking rates increased by about $30 \%$. The sinking rates of cells removed from the dark treatments and placed in saturating irradiance for $3 \mathrm{~h}$ also showed the same trend as the dark sinking rates but much larger overall changes in sinking rate (open symbols, Fig. 2B i). Except for $t=0$, all sinking rates in the light were significantly lower (by $>50 \%$ ) than dark sinking rates.

Cultures grown at limiting irradiances (10 to $40 \mu \mathrm{mol}$ photons $\mathrm{m}^{-2} \mathrm{~s}^{-1}$ ) and placed in the dark for various periods up to $200 \mathrm{~h}$ had significantly higher sinking rates $(>2 \times)$ than cells grown at saturating irradiance and placed in the dark for the same period (data not shown). As explained in the 'Materials and methods' section, no time trends in these particular data will be discussed because of significant overall decreases in cell volume and sinking rate in maintenance cultures over the 18 mo period of the experiments. This did not affect the continuous time series data.

For Ditylum brightwellii, results are shown from a previous paper (Waite et al. 1992b). After $36 \mathrm{~h}$ of dark treatment, there was a significant increase in sinking rates over time until $220 \mathrm{~h}$ (Fig. 2C i) both when sinking rates were measured in the dark (closed symbols) and in the light (open symbols; Fig. 2Ci). Cell volume and cell carbon content both decreased in the dark over the time series (Fig, $2 \mathrm{C}$ ii, iii).

\section{Solitary species: general patterns}

For all experiments including cultures under a variety of constant irradiances (shown in Fig. 1) and time series measurements during dark treatment (shown in Fig. 2), the sinking rates of Thalassiosira pseudonana were correlated with cell carbon content (Fig. 3A i). For the experiments at constant irradiance, this correlation was driven by the strong correlation between cell volume and cell sinking rate (Fig. 3A ii). For the dark per- 


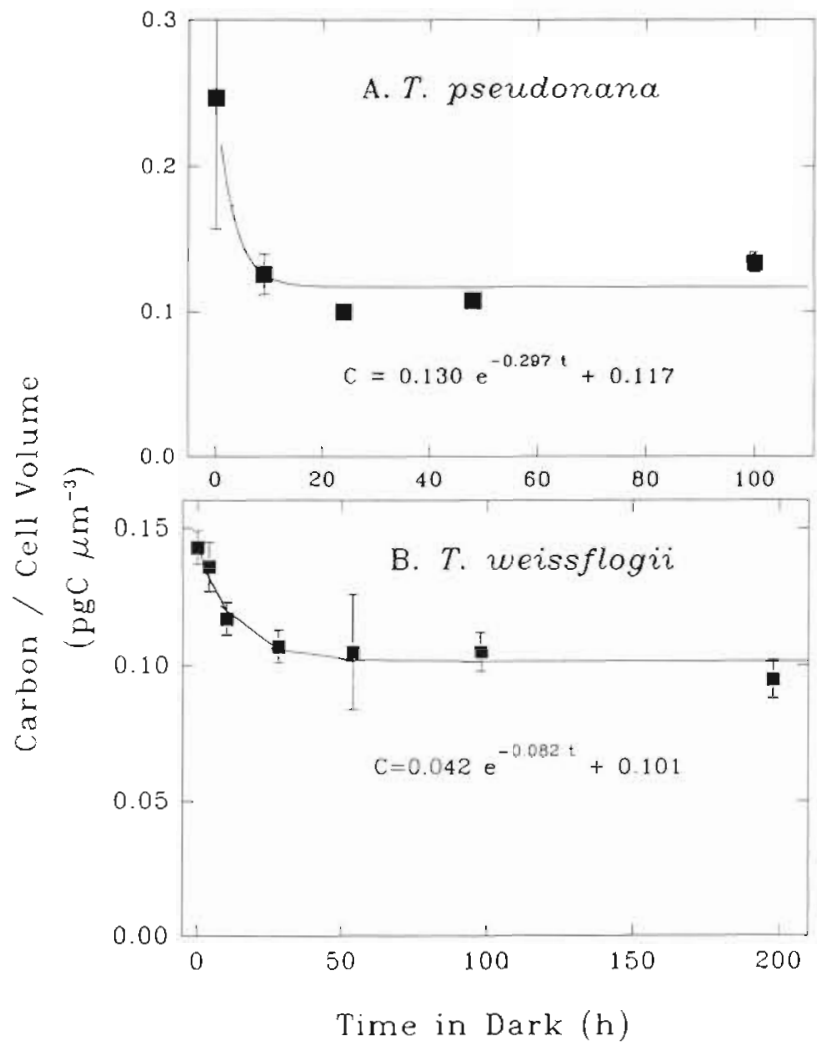

Fig. 4. (A) Thalassiosira pseudonana and (B) T. weissflogii. The change in $C$ per cell over time in the dark, used to calculate cell respiration rates (RR). Note the poor constraint around the first time point for $T$. pseudonana which prevents the use of the estimated RRs for anything but a rough trend with time, in contrast to the well-defined curve for $T$ weissflogii. Equations represent model results for a decreasing exponential curve for each data set

turbations, the correlation was driven by the relationship between sinking rate and carbon per unit cell volume (Fig. 3 A iii). There was no similar overall correlation among treatments between sinking rate and cell carbon content for cultures of $T$. weissflogii (Fig. 3B) or for Ditylum brightwellii (Waite et al. 1992b).

For Thalassiosira weissflogii, and $T$. pseudonana, changes in $\mathrm{C}$ per unit cell volume fit the curves $\mathrm{C}=$ $a e^{-b t}+C$, resulting in $C=0.042 e^{-0082 t}+0.101$ and $C=$ $0.130 e^{-0.297 t}+0.177$ for $T$. weissflogii and $T$. pseudonana respectively (Fig. $4 \mathrm{~A}, \mathrm{~B}$ ). Respiration rates were calculated as the first derivative of this equation $(R R=$ $\left.a b e^{-b t}\right)$. There was no relationship between estimated respiration rate and cell sinking rates for $T$. pseudonana (Fig. 5A). For $T$. weissflogii there was no sinking rate change over a wide range of respiration rates

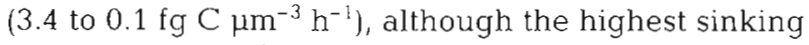
rates $\left(0.14 \mathrm{~m} \mathrm{~d}^{-1}\right)$ did occur as the respiration rate approached $0 \mathrm{fg} \mathrm{C} \mathrm{mm}^{-3} \mathrm{~h}^{-1}$ (Fig. 5B). For Ditylum brightwellii, there was a much clearer inverse relation- ship between sinking rate and respiration rate (Fig. 5C). Estimated respiration rates for healthy cultures before dark treatment (using $t=0$ in the RR equation above) were highest for $T$. pseudonana (72 fg C $\mu \mathrm{m}^{-3} \mathrm{~h}^{-1}$ ) (though the poor constraint around the initial $\mathrm{C} /$ cell measurement makes this a very rough esti-

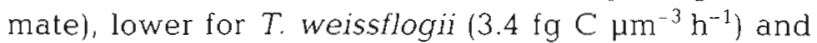

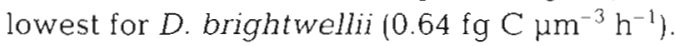

Thalassiosira pseudonana showed an initial positive correlation between cell volume and sinking rate within cultures undergoing dark treatment which did not change over time in the dark (Fig. 6A). For $T$. weissflogii, there was no correlation between sinking

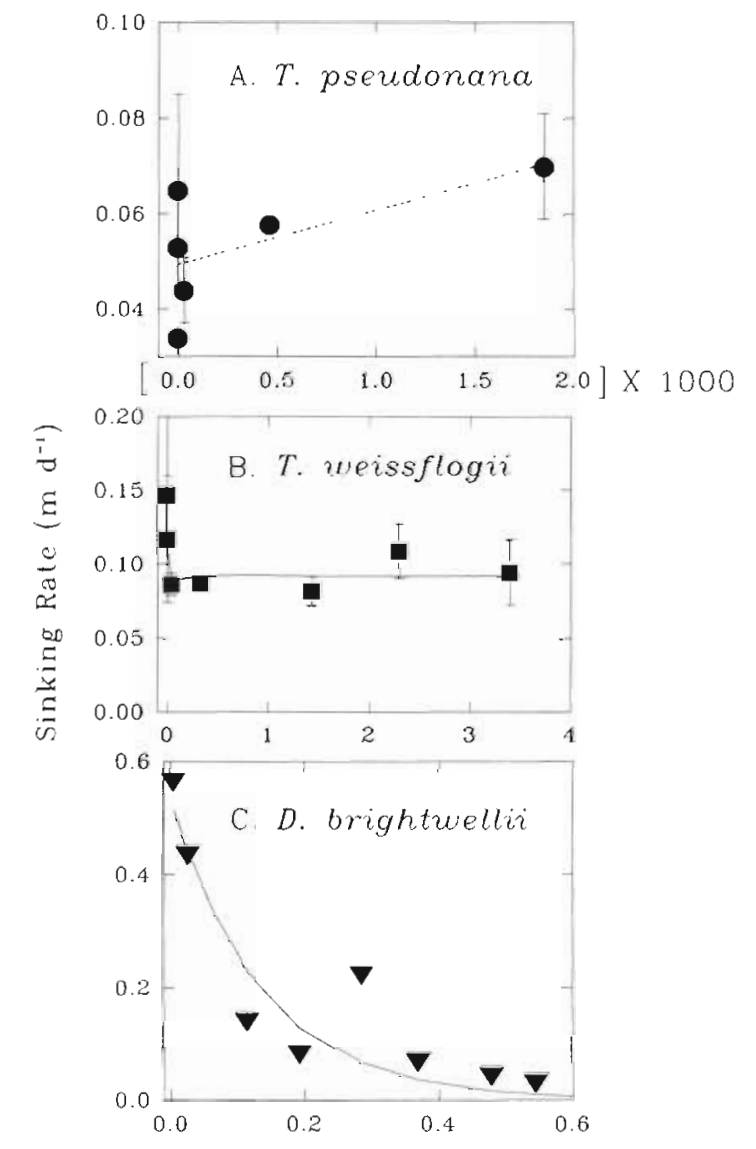

Estimated Respiration Rate (fg $C \mu \mathrm{m}^{-3} \mathrm{~h}^{-1}$ )

Fig. 5. Cell sinking rates vs estimated cell respiration rates for 3 diatoms. (A) For Thalassiosira pseudonana, the actual magnitude of the RR estimate is poorly constrained and is used only to indicate the general trend (i.e. no relationship between RR and sinking rates for this species). (B) For $T$. weissflogii, the RR is a well-constrained estimate based on change in total $\mathrm{C}$ per total biovolume in the dark-treated cultures over time. Curve is a decreasing exponential curve fitted to the data. (C) RR vs sinking rates for Ditylum brightwellii, as in Waite et al. (1992b). Curve as in (B) 


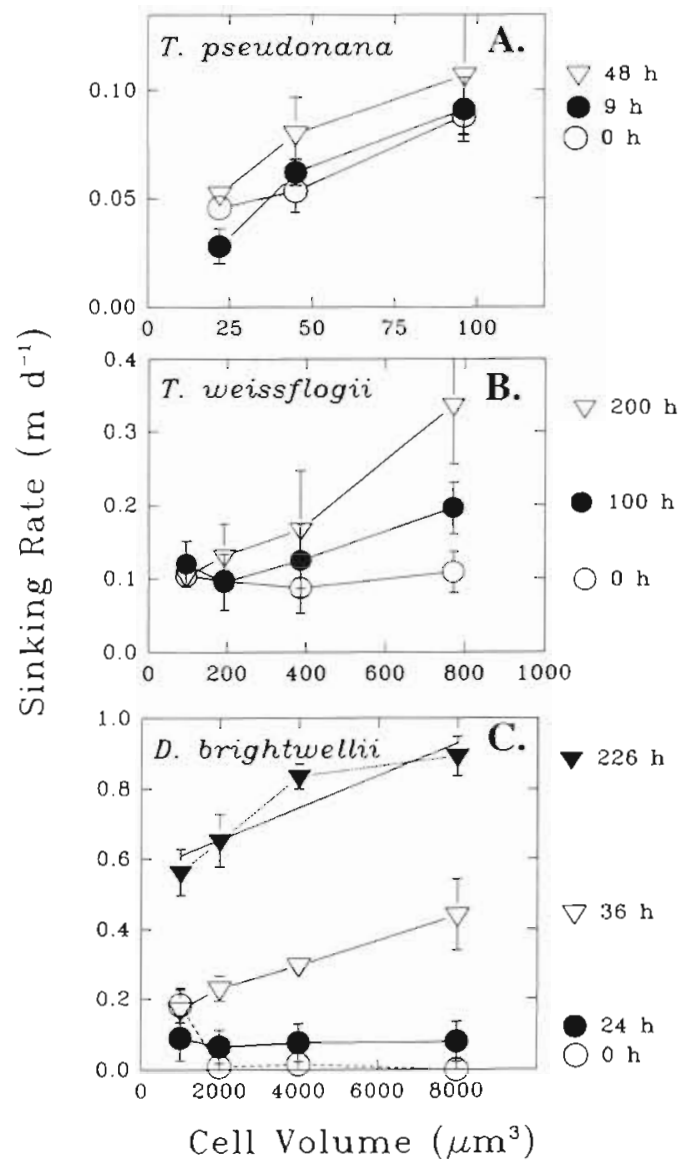

rate and cell volume at $0 \mathrm{~h}$ darkness, since the largest and smallest cells had similar sinking rates (Fig. 6B). The largest cells had higher sinking rates after $100 \mathrm{~h}$ in the dark, and after $200 \mathrm{~h}$ there was overall a significant positive relationship between cell volume and cell sinking rate. Ditylum brightwellii had a pattern similar to that of $T$. weissflogii but the emergence of a significant correlation between cell volume and cell sinking rate within the cultures occurred much earlier (after $36 \mathrm{~h}$ of darkness; Waite et al. 1992b). In addition, the magnitude of total sinking rate increase over the same time period of darkness was much greater for $D$. brightwellii than for T. weissflogin (Fig. 6B, C).

When the sinking rate versus cell volume relationships of the 3 solitary species (Fig. 6A-C) were plotted together on a log-log plot (Fig. 6D), the maximum sinking rates attained by all species (achieved experimentally through the longest dark treatment) fell along a single straight line described by the equation $\mathrm{SR}=$ $0.02 r^{1.6}$, where $\mathrm{SR}=$ sinking rate in $\mathrm{m} \mathrm{d}^{-1}$, and $r=$ equivalent spherical cell radius. Volume-sinking relationships within cultures of Thalassiosira weissflogii and Ditylum brightwellii were significantly different in cultures under energy saturation $(0 \mathrm{~h})$ than in cultures under energy deprivation after prolonged dark expo-

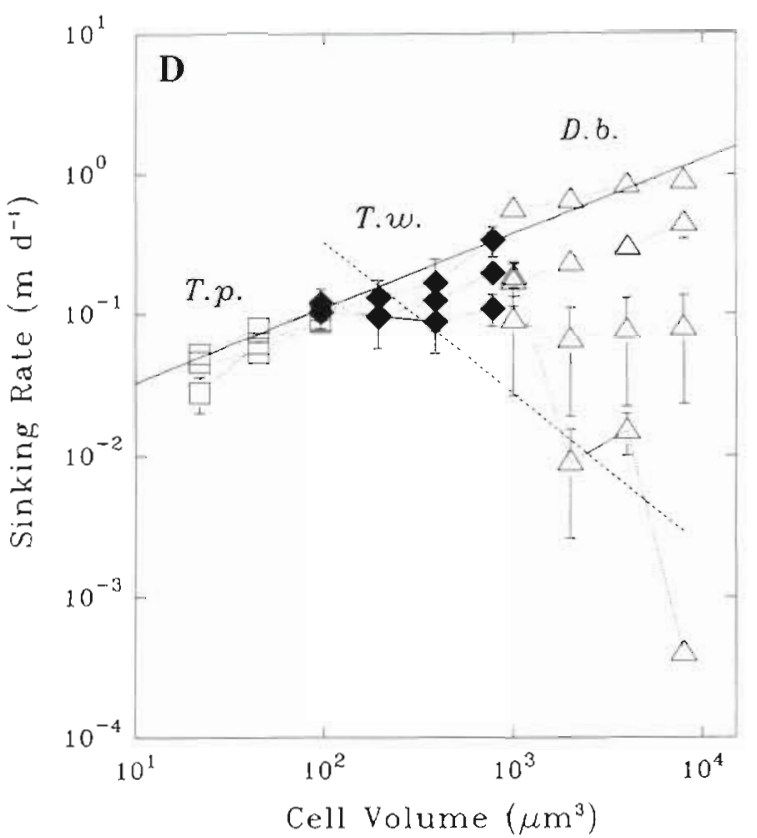

Fig. 6. (A) Thalassiosira pseudonana, (B) $T$ weissflogii, (C) Ditylum brightwellii (from Waite et al. 1992b). Relationship between cell volume and cell sinking rates for 3 diatom species after different periods of dark exposure. All cultures were grown at a saturating irradiance and continuous light and placed in the dark for periods up to $226 \mathrm{~h}$. Time in dark is indicated at the right-hand margin of each figure. $(0 \mathrm{~h}=$ unperturbed culture with sinking rates measured in the light.) (D) Data from $(A),(B)$ and $(C)$ plotted on the same log-log scale. $(\square) T$. pseudonana, $(\downarrow) T$ weissflogii, $(\Delta) D$. brightwellii. Note that the upper curve for each species represents the volumesinking relationship for the most energy-deprived cells. Across all 3 species, the upper-most curve indicates that volume is proportional to $r^{1.6}$, where $r$ is the equivalent spherical radius of the diatom cell. The lower curve is fitted to the energy-saturated sinking rates for $T$ weissflogii and $D$. brightwellii only. Where the 2 curves cross gives an estimate of the cell volume (ca $200 \mathrm{\mu m}^{3}$ ) below which cells cannot fully regulate their sinking rate physiologically, which represents a lower limit to Villareal's (1988) theoretical minimum volume necessary for cell buoyancy. All measurements represent means from 3 or more cultures $\pm 1 \mathrm{SD}$, and where not visible, error bars are smaller than symbol size

sure (200 to $226 \mathrm{~h})$, as indicated in Fig. 6A-C. The regression line through the sinking rate versus volume relationship for exponentially growing cells under light saturation ( $0 \mathrm{~h}$ data) across both these species was significant and negative (Fig. 6D).

\section{Other species}

For Thalassiosira aestivalis and Skeletonema costatum, cells treated for $3 \mathrm{~h}$ of darkness with $\mathrm{KCN}$ as a respiratory inhibitor showed a significant increase in 

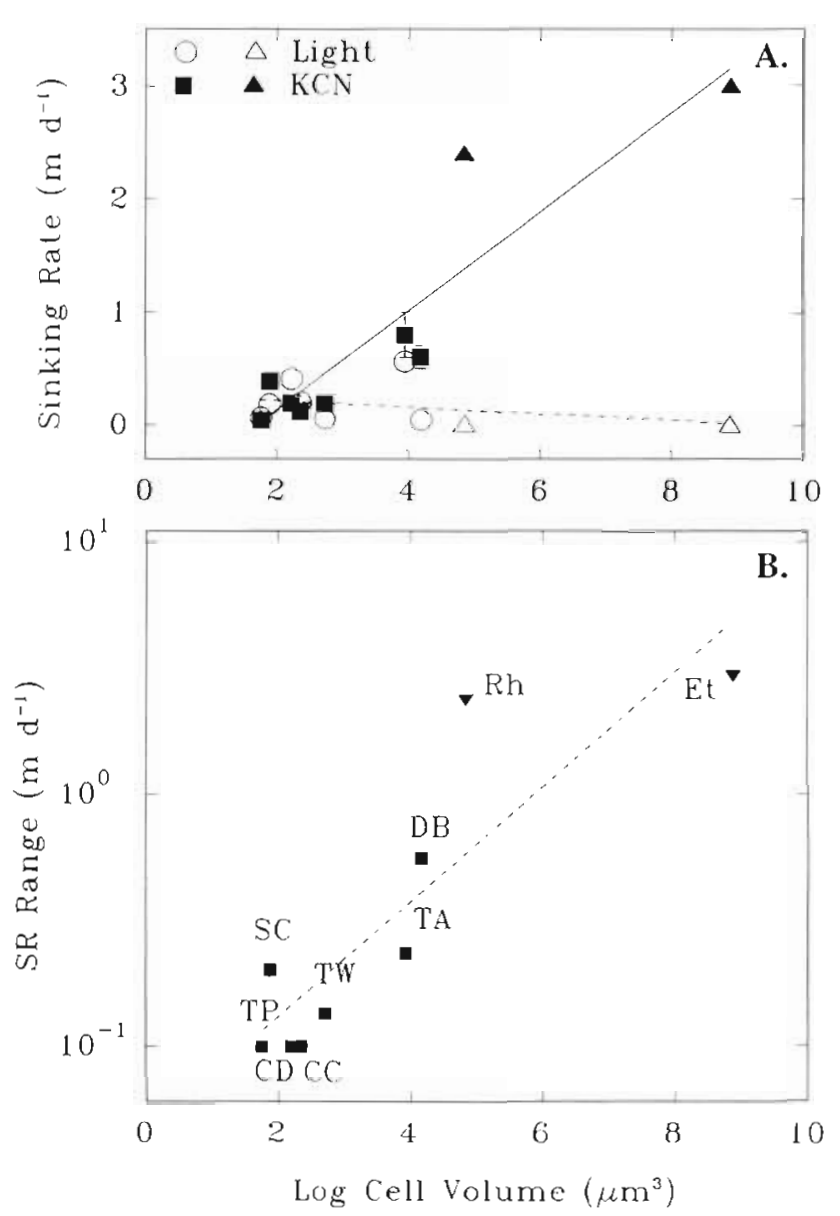

Fig. 7. Sinking rates of 9 species of marne diatoms vs mean cell volume. (A) Sinking rates of cells grown and kept in the light, including cells grown in the laboratory at saturating irradiance (O), and field samples whose sinking rates were measured after cells were brought on board $(\Delta)$. Filled symbols indicate sinking rates of KCN-treated cells of laboratory grown cells ( $\mathbf{\square}$ ) and field samples (A). (B) Log sinking rate range of all species, measured as $\mathrm{KCN}$-sinking rate minus the light-saturated sinking rate, vs log cell volume (ם). A.ll measurements represent means from 3 or more cultures \pm 1 SD, and error bars are sometimes smaller than symbol size. The abbreviations indicate individual species as follows: $C C$, Chaetoceros compressum; CD, C. debulis; DB, Ditylum brightwellii, Et, Ethmodiscus sp.; Rh, Rhizosolenia spp.; SC, Skeletonema costatum; TA, Thalassiosira aestivalis; TP, T. pseudonana; TW, $T$ weissflogii

sinking rates $(\mathrm{p}<0.05, \mathrm{n}=3$ ). For Chaetoceros compressum and $C$. debilis, $\mathrm{KCN}$-treated cells showed no difference in sinking rates compared to cells sinking in the light. Floating cells of Ethmodiscus sp. and floating mats of Rhizosolenia spp. sank within $3 \mathrm{~h}$ of $\mathrm{KCN}$ treatment. When plotted as a group, the KCN-treated cells of all species showed a significant positive relationship between cell volume and sinking rate (Fig. $7 \mathrm{~A}$; closed symbols), while there was no relationship for metabol- ically active, rapidly growing cells (Fig. $7 \mathrm{~A}$; open $5 y \mathrm{~m}$ bols). This relationship was then plotted as the difference between the sinking rate of energy-saturated cells and KCN-treated cells (i.e. maximum-minimum) versus cell volume for all 9 species studied, and showed a significant positive correlation between sinking rate range and cell volume (Fig. 7B). The even distribution of points along the $\log$ - $\log$ plot indicated that the significant correlations in Fig. $7 \mathrm{~A}, \mathrm{~B}$ were not driven by 1 or 2 points alone, but were a true reflection of the relationship between cell volume and sinking rate.

\section{DISCUSSION}

In accordance with Stokes' Law, the maximum sinking rates of large diatom cells are higher than those of small cells. Thus, when all cells within a culture are sinking at their maximum rate, there is a positive correlation between cell volume and sinking rate (Waite et al. 1992b). In this study, the maximum slope of the sinking rate versus cell volume relationship within a culture also occurred for cells which were severely stressed metabolically through prolonged dark treatment (Fig. 6D). The minimum slope occurred within cultures of rapidly dividing cells able to reduce the sinking rates of all size classes to similar values. Intermediate cases were found for cells in intermediate physiological states. We suggest that the ability of a diatom to control its sinking rate physiologically under different conditions can be summarized as their ability to reduce the slope of the sinking rate versus cell volume relationship.

\section{Solitary species}

The clear relationship between cell volume and sinking within cultures of Thalassiosira pseudonana across all conditions studied (Fig. 6A) indicated that carbon ballasting dominated sinking rate control. This relationship, combined with data on cell carbon content $(C$ cell ${ }^{-1}$ ), reveals key details of this control in $T$. pseudonana. For example, mean cell volume was lowest in cultures grown at the lowest irradiance (as in Thompson et al. 1991), and such volume differences were correlated directly with sinking rate changes across the 4 cultures kept under continuous light. In this case, C per cell volume remained constant. Under dark perturbation, however, $C$ per cell changed more rapidly than cell volume over time in the dark, and it was $C$ content that seemed to drive sinking rate changes. Though both $\mathrm{C}$ per cell and $\mathrm{C}$ per unit cell volume covaried with sinking rates, $C$ per unit cell volume described a 
higher portion of the variance in sinking rates than volume alone.

The sinking rate versus volume relationship in the time series experiment remained constant over time in the dark. Most notable is the positive relationship between volume and sinking rate at the beginning of the experiment, when cells were growing exponentially at saturating irradiance. This clearly indicted that even when metabolically active, the sinking rate of Thalassiosira pseudonana is driven primarily by ballasting and cell size, not by energetic vacuole control.

The only indication that Thalassiosira pseudonana sinking rate depended on an active metabolism at all emerged when we measured cultures grown at limiting irradiances which were placed in the dark (data not shown). The fact that sinking rates were significantly higher in light-limited cells in these 4 treatments than for cells grown at a saturating irradiance in identical treatments indicates that there is in fact a measurable $\left(0.025 \mathrm{~m} \mathrm{~d}^{-1}\right)$ energetic component to sinking rate control in $T$. pseudonana. Variation in cell volume however could account for larger changes, up to $0.05 \mathrm{~m}$ $\mathrm{d}^{-1}$, and were more commonly correlated with sinking rates. This type of sinking rate control mechanism is similar to that found in cyanobacteria (Walsby \& Brooker 1980, Kromkamp et al. 1988, Ibelings et al. 1991).

In contrast, the lack of correlation between cell volume or cell carbon content and sinking rate over a variety of growth irradiances for Thalassiosira weissflogii suggests that volume and carbon content are not primary determinants of variation in cell sinking rate for $T$. weissflogii. This is confirmed by the studies by Fisher et al. (1996) and Fisher \& Harrison (1996) suggesting that carbohydrate content of $T$. weissflogii and Ditylum brightwellii does not correlate systematically with sinking rate changes.

Cell volume does play some role in the sinking dynamics of Thalassiosira weissflogii cells in the dark. Light-saturated cells of $T$. weissflogii placed in the dark underwent a transient ( $30 \mathrm{~h}$ ) sinking rate reduction which correlated (across all 3 cultures) with cell volume and carbon content. Cell volume changes accounted for $-20 \%$ of the sinking rate variance between 0 and $30 \mathrm{~h}$ in the dark, and the residual changes were probably caused by the relaxation of ion pumps in the vacuole as described in more detail by Peters (unpubl.). Physiological factors independent of volume also caused sinking rate increases after $30 \mathrm{~h}$ in the dark, most likely a reduction in respiration rate, since the highest sinking rate occurred at the lowest respiration rates estimated.

The largest cells of Thalassiosira weissflogii showed a significant increase in sinking rate at $100 \mathrm{~h}$, and a larger increase by $200 \mathrm{~h}$, developing a significant rela- tionship between sinking rate and cell volume. This suggests that this species loses metabolic control of sinking rate under energy deprivation. However, the mean sinking rates of all cells in the cultures after dark treatment were never significantly higher than those at $t=0$. This was a key example in which the slope of the volume-sinking rate relationship was more sensitive to physiological stress than the mean sinking rate of the cultures. In fact, the slope of the sinking rate-volume relationship increased in a manner similar to that of Ditylum brightwellii, but with a smaller difference between minimum (energy-saturated) and maximum (energy-limited) sinking rate. The relative changes in cell volume, and the change in overall respiration rate for $T$. weissflogii are also much smaller over the same time period. Though following a similar pattern, the sinking rate of $T$. weissflogii appears much more resilient to dark treatment than $D$. brightwellii, due perhaps to the cells undergoing physiological changes more slowly over time in the dark.

Bienfang et al. (1983) suggested that sinking rates were lower at lower irradiances for Thalassiosira weissflogii, which differs from the results in our study. Sinking rates were measured over $6 \mathrm{~h}$ of darkness in the Bienfang et al. (1983) study and may thus have represented the transient response of cells to darkness. Such cells differ physiologically from cells sinking in the light (Waite et al. 1992b. Peters unpubl.). However, their conclusions that sinking reduction can contribute to chlorophyll maximum formation would certainly hold over several hours of darkness (e.g. at night).

Remarkably, the maximum sinking rates of all 3 solitary species fall on a single line when plotted versus cell volume, and the regression line is proportional to cell radius to the 1.6 power, very close to that of Stokes' Law (SR proportional to $r^{2}$ ). This strongly suggests that the sinking rates of all 3 species are similarly constrained by size both within and between cultures. The slope of the regression through the minimum sinking rate of the 3 species is proportional to $r^{1.2}$, and represents the sinking rate reduction potentially achievable through physiological modification; naturally, the magnitude of this potential increases with cell size, and the difference between the maximum and minimum curves increases directly with cell volume. Recent work by Moore \& Villareal (1996) documents a clear positive relationship between cell volume (V) and ascent rate $(A R)$ in the largest diatom species, where $A R \propto V^{0.89}$. Our negative relationship between minimum SR and cell volume (dashed line, Fig. 6D) can be inverted and expressed as a positive change in $A R$. This would indicate $A R \propto V^{0.83}$, a remarkably similar relationship. This suggests that the patterns seen in small sinking diatoms may extend into upper size classes, and vice versa. 
The maximum and minimum curves converge at a cell volume of $200 \mu^{3}$, suggesting that this represents a minimum cell volume (MCV) below which the cells cannot regulate their buoyancy physiologically but are constrained by cell size. From the curves in Fig. 7 we estimate a strikingly similar value for the MCV, since the 2 curves cross at ca $190 \mu^{3}$. The MCV would represent a lower constraint on the theoretical minimum volume necessary for positive buoyancy originally postulated by Villareal (1988) and supported by Moore \& Villareal (1996). Based on our results in the smaller size classes, and experimental measurements on Ditylum brightwellii, whose largest cells can become positively buoyant, we would estimate Villareal's theoretical minimum volume for buoyancy should lie somewhere near $8.0 \times 10^{3} \mu^{3}$.

\section{Other species}

The lack of correlation between sinking rate and cell volume for rapidly growing cultures of chain-forming diatoms kept at saturating irradiances suggests that there is no obligate correlation between cell volume and sinking rate for metabolically active cells across a wide variety of species. This absence of significant volume versus sinking rate relationship in energy-saturated cells is similar to that found for actively growing chain-formers in culture by Smayda (1970; his Fig. 2), but the positive relationship he documented between cell volume and sinking rate for actively growing unicellular species is not supported by our study. Our minimum sinking rates for light-saturated Ditylum brightwellii $\left(0.02 \mathrm{~m} \mathrm{~d}^{-1}\right)$, for example, are an order of magnitude lower than those in his study $\left(0.5 \mathrm{~m} \mathrm{~d}^{-1}\right)$, and show either no relationship or a negative correlation with cell volume within a culture. It is possible that the cells from Smayda's Fig. 1, though actively growing, were either not growing at $\mu_{\max }$ or for some other reason not sinking at their absolute minimum rate.

The significant correlation between cell volume and cell sinking rate for $\mathrm{KCN}$-treated cells demonstrates again how physical considerations determine cell sinking rates once the active physiological component of sinking rate control is blocked or unavailable. These relationships seem to hold both within species (as discussed above) and between species. One would not expect a priori that chain-forming diatoms would fall on the same line as solitary species, since the physical characteristics of the chains themselves can impact the final sinking rate (Smayda 1970, Waite et al. 1992b). The fact that they do (Fig. 7A, B) suggests similar processes control the sinking rate of both chain-forming and solitary diatoms. However, chains are often longer in nature than in culture and would be expected to have a more significant effect on sinking rate in nature than might be measured in our study (Moore \& Villareal 1996).

\section{Overview}

The achievement of low or negligible sinking rates under optimal growth conditions can reduce the slope of the volume versus sinking rate relationship to zero or lower in species that actively regulate their buoyancy. This feature allows us to functionally differentiate 2 different components of sinking rate control, the active, energy-requiring, vacuolar/protoplast turgor component which is volume independent and the passive component which is driven by changes in biochemical ballasting and volume.

The results presented here indicate that of the 3 solitary species examined, Ditylum brightwellii $\left(8000 \mu \mathrm{m}^{3}\right)$ showed a positive slope and had a high energetic requirement for sinking rate control, Thalassiosira weissflogii $\left(600 \mathrm{\mu m}^{3}\right)$ had some energetic requirement for sinking rate control, and $T$. pseudonana $\left(60 \mu^{3}\right)$ had minimal energetic sinking rate control. When plotted against cell volume, the maximum sinking rate for all 3 species described a linear relationship with sinking rate roughly proportional to the square of the equivalent spherical radius (sinking rate $\propto r^{1.6}$ ) as suggested by Stokes' Law. Across a wide range of diatoms, including solitary species, chain-forming species and large oceanic diatoms, the larger cells showed a greater reduction from their maximum rate suggesting a larger energetic component for these cells. This held true both within cultures of a single species and between cultures of 9 different species. We suggest that the minimum cell volume necessary for active sinking rate control is ca $200 \mu^{3}$, and that this represents a lower limit for Villareal's (1988) minimum volume necessary for positive buoyancy.

Our results also suggest that quantification of the patterns of physiological cell buoyancy regulation will be important when estimating broader relationships between particle mass and particle size for the prediction of particle flux in the ocean (Jackson et al. 1995 , Jonasz \& Fournier 1996). If physiological sinking rate changes are amplified into size categories far larger than a single cell through incorporation into chains or aggregates (e.g. Riebesell 1992), buoyancy regulation may significantly impact vertical fluxes.

Acknowledgements. This work was supported by a Natural Sciences and Engineering Research Council of Canada grant to P.J.H. and a Post-doctoral Fellowship to A.W. A.W. was also supported by a Woods Hole Oceanographic Institution Post- 
doctoral Scholarship. We thank T. Villareal for the opportunity to study the floating diatoms of the Pacific and K. Moore for help at sea. All field work was supported by the National Science Foundation, Grant No. OCE9100888 to T. Villareal.

\section{LITERATURE CITED}

Anderson L, Sweeney B (1977) Diel changes in the sedimentation characteristics of Ditylum brightwellii, a marine centric diatom: changes in cellular lipids and effects of respiratory inhibitors and ion-transport modifiers. Limnol Oceanogr 22:539-552

Bienfang PK (1981) SETCOL-a technologically simple and reliable method for measuring phytoplankton sinking rates. Can J Fish Aquat Sci 38:1289-1294

Bienfang P, Szyper J, Laws E (1983) Sinking rate and pigment responses to light-limitation of a marine diatom: implications to dynamics of chlorophyll maximum layers. Oceanol Acta 6:55-62

Eppley RW, Holmes RW, Strickland JDH (1967) Sinking rates of marine phytoplankton measured with a fluorometer J Exp Mar Biol Ecol 1:191-208

Fisher AE, Berges JA, Harrison PJ (1996) Does light quality affect the sinking rates of marine diatoms? J Phycol 32: 353-360

Fisher AE, Harrison PJ (1996) Does carbohydrate content affect the sinking rates of marine diatoms? J Phycol 32: $360-365$

Goering JC, Patton CJ, Shields WW (1973) Nutrient cycles. In: Hood EW, Shields WW, Kelley EJ (eds) Environmental studies of Port Valdez. Univ of Alaska, Fairbanks, Inst Mar Sci Occ Pub] 2:253-271

Gross F, Zeuthen E (1948) The buoyancy of plankton diatoms: a problem of cell physiology. Proc R Soc Lond Ser B 135: 382-389

Harrison PJ, Waters RE, Taylor FJR (1980) A broad spectrum artificial seawater medium for coastal and open ocean phytoplankton. J Phycol 16:28-35

Ibelings BW, Mur LR, Kinsman R, Walsby AE (1991) Microcystis changes its buoyancy in response to the average irradiance in the mixed layer. Arch Hydrobiol 120: $385-401$

Jackson GA, Lochmann S (1993) Modelling coagulation of algae in marine ecosystems. In: Baffle J, van Leeuwen $\mathrm{HP}$ (eds) Environmental particles, Vol 2. Lewis Publishers, Chelsea, MI, p $387-414$

Editorial responsibility: Otto Kinne, Oldendorf/Luhe, Germany
Jackson GA, Logan BE, Alldredge AL, Dam HG (1995) Combining particle size spectra from a mesocosm experiment measured using photographic and aperture impedance (Coulter and Elzone) techniques. Deep Sea Res II 42: $139-147$

Jonasz $M$, Fournier $G$ (1996) Approximation of the size distribution of marine particles by a sum of log-normal functions. Limnol Oceanogr 41:744-754

Kromkamp J, Konopka A, Mur LR (1988) Buoyancy regulation in light-limited cultures of Microcystis aeruginosa J Plankton Res 10:171-183

Kromkamp JA, Mur LR (1984) Buoyant density changes in the cyanobacterium Microcystis aeruginosa due to changes in cell carbohydrate content. FEMS Microbiol Lett 25 $105-109$

Moore JK, Villareal TA (1996) Size-ascent rate relationships in positively buoyant marine diatoms. Limnol Oceanogr 41:1514-1520

Parsons TR, Maita Y, Lalli CM (1984) A manual of chemical and biological methods for seawater analysis. Pergamon, Oxford

Riebesell U (1992) The formation of large marine snow and its sustained residence in surface waters. Limnol Oceanogr $37: 63-76$

Smayda TJ (1970) The suspension and sinking of phytoplankton in the sea. Oceanogr Mar Biol Annu Rev 8:353-414

Smetacek VS (1985) Role of sinking in diatom life history cycles: ecological, evolutionary and geological significance. Mar Biol 84:239-251

Thompson PA, Harrison PJ, Parslow JS (1991) Influence of irradiance on cell volume and carbon quota for ten species of marine phytoplankton. J Phycol 27:351-360

Villareal TA (1988) Positive buoyancy in the oceanic diatom Rhizosolenia debayana H Peragallo. Deep Sea Res 35 $1037-1045$

Villareal TA, Carpenter EJ (1990) Diel buoyancy regulation in the marine diazotrophic cyanobacterium Trichodesmium thiebautii. Limnol Oceanogr 35:1832-1837

Waite A, Bienfang PK, Harrison PJ (1992a) Spring bloom sedimentation in a subarctic ecosystem. 1: Nutrients and sinking. Mar Biol 114:119-129

Waite A, Thompson PA, Harrison PJ (1992b) Does energy control the sinking rates of marine diatoms? Limnol Oceanogr 37:468-477

Walsby AE, Brooker MJ (1980) Changes in buoyancy of a planktonic blue-green alga in response to light intensity. Br Phycol J 15:311-319

Submitted: June 13, 1997; Accepted: June 16, 1997 Proofs received from author(s): September 23, 1997 